\title{
SOEP
}

SOEPpapers

on Multidisciplinary Panel Data Research
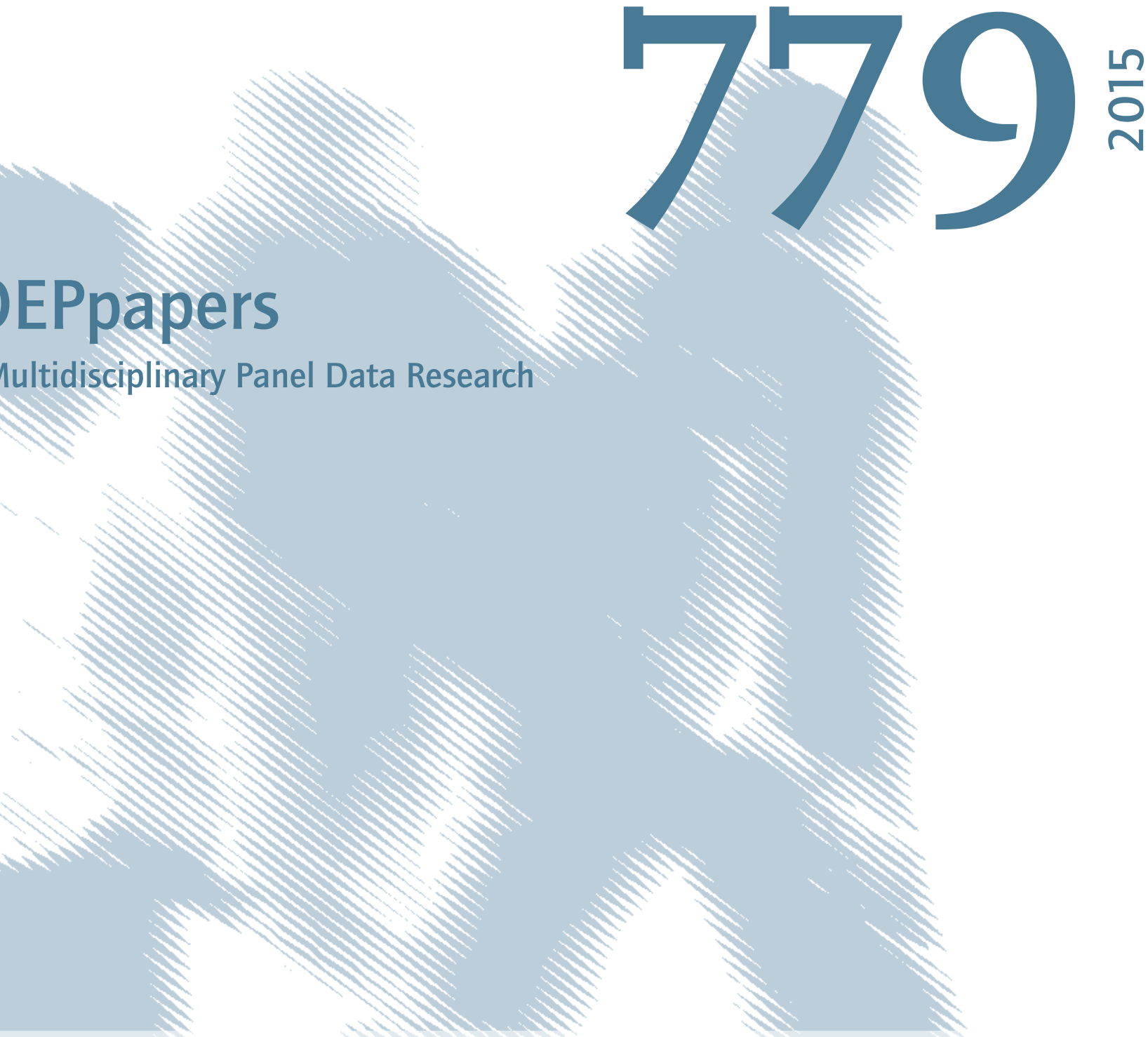

\section{Measuring Renewable Energy Externalities: Evidence from Subjective Well-Being Data}


This series presents research findings based either directly on data from the German SocioEconomic Panel study (SOEP) or using SOEP data as part of an internationally comparable data set (e.g. CNEF, ECHP, LIS, LWS, CHER/PACO). SOEP is a truly multidisciplinary household panel study covering a wide range of social and behavioral sciences: economics, sociology, psychology, survey methodology, econometrics and applied statistics, educational science, political science, public health, behavioral genetics, demography, geography, and sport science.

The decision to publish a submission in SOEPpapers is made by a board of editors chosen by the DIW Berlin to represent the wide range of disciplines covered by SOEP. There is no external referee process and papers are either accepted or rejected without revision. Papers appear in this series as works in progress and may also appear elsewhere. They often represent preliminary studies and are circulated to encourage discussion. Citation of such a paper should account for its provisional character. A revised version may be requested from the author directly.

Any opinions expressed in this series are those of the author(s) and not those of DIW Berlin. Research disseminated by DIW Berlin may include views on public policy issues, but the institute itself takes no institutional policy positions.

The SOEPpapers are available at http://www.diw.de/soeppapers

\section{Editors:}

Jan Goebel (Spatial Economics)

Martin Kroh (Political Science, Survey Methodology)

Carsten Schröder (Public Economics)

Jürgen Schupp (Sociology)

Conchita D'Ambrosio (Public Economics)

Denis Gerstorf (Psychology, DIW Research Director)

Elke Holst (Gender Studies, DIW Research Director)

Frauke Kreuter (Survey Methodology, DIW Research Fellow)

Frieder R. Lang (Psychology, DIW Research Fellow)

Jörg-Peter Schräpler (Survey Methodology, DIW Research Fellow)

Thomas Siedler (Empirical Economics)

C. Katharina Spieß (Education and Family Economics)

Gert G. Wagner (Social Sciences)

ISSN: 1864-6689 (online)

German Socio-Economic Panel Study (SOEP)

DIW Berlin

Mohrenstrasse 58

10117 Berlin, Germany

Contact: Uta Rahmann | soeppapers@diw.de 


\title{
Measuring Renewable Energy Externalities:
}

\section{Evidence from Subjective Well-Being Data}

\author{
Charlotte von Möllendorff \\ Heinz Welsch \\ Department of Economics \\ University of Oldenburg \\ 26111 Oldenburg, Germany
}

\begin{abstract}
Electricity from renewable sources avoids disadvantages of conventional power generation but often meets with local resistance due to visual, acoustic, and odor nuisance. We use representative panel data on the subjective well-being of 46,678 individuals in Germany, 1994-2012, for identifying and valuing the local externalities from solar, wind and biomass plants in respondents' postcode area and adjacent postcode areas. We find significant wellbeing externalities of all three technologies that differ with regard to their temporal and spatial characteristics. The monetary equivalent of $1 \mathrm{MW}$ capacity expansion is estimated to be in the range of 0.3-0.7 percent of per capita income.
\end{abstract}

Keywords: renewable energy; local externality; subjective well-being; life satisfaction; nonmarket valuation

JEL codes: Q42; D62; I31; Q51

Acknowledgements: We are grateful to Jürgen Bitzer, Erkan Gören, Philipp Biermann and Daniel Lückehe for useful comments and support. 


\section{Introduction}

Electricity generation from renewable sources is rapidly expanding in many countries around the world. In Germany, the share of electricity generated from Renewable Energy (RE) sources in total electricity consumption has increased from $4.6 \%$ in 1994 to $23.7 \%$ in 2012 . In the European Union, we observe the same trend; by 2012, the share of RE sources in total electricity consumptions amounted to $23.5 \%$.

The public attitude towards RE is typically favorable (VZBV 2013), because renewable power avoids the externalities associated with electricity from fossil fuels (air pollution and greenhouse gases) and nuclear power (nuclear risk and waste disposal). Consistent with voiced opinions, Welsch and Biermann (2014) found in a multi-country study, that a higher share of solar and wind power in a country's national electricity mix is associated with greater subjective well-being of its citizens.

In spite of smaller large-scale externalities (environmental pollution), renewable power facilities may induce externalities on the local scale, such as visual impairments in the case of solar and wind power and odor nuisance in the case of biomass plants. In fact, the installation of such facilities often meets with local resistance, reflecting the so-called not-inmy-backyard (NIMBY) issue (van der Horst 2007) and, more generally, social and community acceptance problems (Batel et al. 2013).

This paper studies such RE externalities from the point of view of local subjective well-being. Specifically, the paper addresses the following aspects of the relationship between RE facilities and residents' well-being: (1) How does the well-being of residents change due to the local expansion of RE? (2) Are there well-being differences between the initial installation in a given place and subsequent expansions? (3) Are there spatial spillovers of RE 
externalities? (4) How do well-being effects of RE installations evolve over time? (5) Do wind, solar, and biomass installations differ in terms of those questions? ${ }^{1}$

With respect to these issues, a number of features of the different technologies may be relevant for their well-being impacts. For instance, rooftop solar installations are typically owned by the residents themselves, whereas wind parks are often the property of external investors. In addition, the impact of solar installations is mainly visual and can be more easily avoided than the odor nuisance from biomass plants. It is intuitive that such differences influence the relationship between the different RE technologies and residents' well-being, and our empirical findings are in line with such expectations.

We use panel data on reported life satisfaction of 46,678 German citizens, 1994-2012, and the number and capacity installed of wind power, solar and biomass plants at the postcode area where the respondents live as well as at the neighboring postcode areas. For each type of RE technology we estimate several specifications of life satisfaction regressions that are designed to address the specific research questions mentioned above.

We find significant negative well-being externalities from all three types of RE, but they differ in several important ways:

For solar power, we find no well-being effects of initial installations, but effects from continuous expansion, and those effects accumulate rather than dissipate over time. From a spatial point of view, mainly solar installations in neighboring postcode areas seem to affect people's well-being, not those in their own postcode area.

For wind power, our results indicate that well-being effects arise both from initial installations and subsequent expansions, though the effects from initial installations are more pronounced. There are no spatial externalities from neighboring postcode areas.

\footnotetext{
${ }^{1}$ We restrict our analysis to those "new" types of RE. The expansion of hydro power has been very limited in Germany over the last decades.
} 
For biomass plants, the estimates suggest the existence of significant negative effects of first installations and expansions on residents' well-being as well as well-being spillovers from adjacent areas.

Regarding the temporal dynamics of well-being externalities, we find significant negative effects preceding the first installation (lead effects) of wind and biomass plants but not from the installation of solar units. The monetary equivalent of $1 \mathrm{MW}$ capacity expansion is estimated to be in the range of 0.3-0.7 percent of equivalized income.

As will be discussed below, these findings for the different technologies are explicable in the light of those technologies' characteristics and respective channels of influence on residents' well-being.

To our knowledge, this paper is the first to study the nature and extent of well-being externalities from solar, wind and biomass energy in a comparative perspective. In relation to previous literature, a major advantage of the present study is the use of a rich set of spatially disaggregated and nationwide representative panel data. This allows us to conduct a longitudinal analysis of externalities associated with RE. The only similar analysis we are aware of was conducted by Krekel and Zerrahn (2015), but that paper focuses exclusively on wind energy.

The paper is structured as follows. Section 2 discusses the background and the relevant literature. Section 3 presents the data and econometric framework. Section 4 reports and discusses the empirical results. Section 5 concludes.

\section{Background and Literature}

During the past decades, especially after the introduction of the Electricity Feed-In Act (Stromeinspeisungsgesetz, StrEG) in 1991 and its successor, the Renewable Energy Act (Erneuerbare-Energien-Gesetz, EEG) in 2000, Germany has faced a wide expansion of RE technologies. By the end of 2012 Germany had 13,611 biomass plants, 21,500, wind turbines, 
and about 1.3 million solar installations falling under the regulations of the EEG, whereas the corresponding numbers for 1994 are 54 biomass plants, 1,118 wind turbines and 1,850 solar installations (source: see data section).

Polls among German citizens yield a considerable support for a transition of the energy system towards RE (see e.g. VZBV 2013). However, in some regions the expansion of RE technologies gave rise to local opposition which, in view of the strong general support of RE, provoked a debate on the so-called not in my backyard (NIMBY) problem (van der Horst 2007). One source of the NIMBY issue consists of the local or regional externalities associated with the different RE technologies. While wind turbines can affect residents via their shadowing, noise as well as influence on the landscape and biodiversity (Drechsler et al. 2011), biogas plants are mainly objected because of odor nuisance, visual impacts or fear of declining tourism or property prices (Soland et al. 2013). Regarding solar power, possible impairments include glare risks and visual impacts on buildings as well as on landscapes in case of free-standing solar plants (Chiabrando et al. 2009).

In addition to such externalities, political science has focused on the broader issue of social acceptance (Wüstenhagen et al. 2007). Among the various dimensions of social acceptance, the one most relevant for local RE externalities is community acceptance, which depends on perceived benefits, fairness considerations, the availability of information, participation options and trust in the operator, just to mention a few (for a review see DevineWright 2007).

Several non-market valuation techniques have been used for quantifying the externalities from RE technologies. Numerous case studies, polls and discrete choice experiments have been conducted to identify the underlying problems of siting conflicts and factors of influence for social acceptance, whereby the bulk of studies focuses on wind energy development projects (van der Horst 2007). Due to differences in methodological designs, 
stated questions and terms used (e.g. acceptance vs. support), the results present quite a mixed picture (Devine-Wright 2007).

In the case of wind power, stated choice experiments tend to show that there can be negative externalities arising from wind turbines, resulting in a positive willingness to pay (WTP) of respondents for an increase in the distance to the nearest wind turbine (for an overview see Meyerhoff et al. 2010). Drechsler et al. (2011) estimate in a choice experiment that external costs make-up approximately $14 \%$ of the total investment costs.

Stated preference methods exhibit some drawbacks as respondents could be inclined to respond strategically if they assume their answers to influence political decisions upon the expansion of RE technologies (Fujiwara and Campbell 2011). Moreover, respondents may give socially desirable answers due to the positive connotation of RE (van der Horst 2007) or misconceive the aspect of adapting and habituating to the impacts of RE technologies (focusing illusion, see Kahneman and Thaler 2006). Meyerhoff (2013) provides evidence of residents' misconception of adaptation and habituation to wind turbines; he finds that people who live further away from wind turbines are more likely opponents of wind power development compared to people who have wind turbines in close proximity (Meyerhoff 2013).

Another strand in the literature on the valuation of non-market goods relies on revealed preference rather than stated preference methods. In the context of local effects of RE siting the hedonic approach has been applied, which reverts to housing market data. Supposed that housing prices reflect the value of non-market goods present in the neighborhood - e.g. proximity to recreational sites, local infrastructure, air quality or noise it is possible to compute the individual WTP for those goods (Fujiwara and Campbell 2011). Several studies have analyzed the effect of wind turbines on property values (see e.g. Sunak and Madlener 2012, Jensen et al. 2013, Hoen et al. 2013). While most of them find a negative effect of wind energy development on property values (e.g. Sunak and Madlener 2012 for the 
state of North Rhine-Westphalia/Germany and Jensen et al. 2013 for Denmark) others do not find property values to be affected by wind turbines - at least not significantly (see e.g. Hoen et al. 2013 for the US).

The present paper applies the experienced preference method (Welsch and Ferreira 2014), also referred to as life satisfaction or happiness approach, in order to analyze effects of RE expansion on well-being and to measure local residents' preferences with regard to the various RE technologies. This method of preference elicitation uses people's reported life satisfaction as a proxy for experienced utility. It estimates the statistical association of life satisfaction to the non-market good (or bad) in question as well as to people's income. The implied utility-constant tradeoff of income for the good is then used as a measure of the monetary value of the latter. The experienced preference method thus provides a tool for nonmarket valuation, in addition to the standard stated and revealed preference methods.

Life satisfaction data have been used in environmental economics (for surveys see Welsch and Kühling 2009, Frey et al. 2010, MacKerron 2012, and Welsch and Ferreira 2014) and, to a smaller extent, with respect to energy issues. Experienced preference studies differ with respect to the spatial resolution, which ranges from whole nations (Welsch 2002, Rehdanz and Maddison 2005) to postcode areas (Levinson 2012) and GPS coordinates (MacKerron and Mourato 2014). With respect to energy, Welsch and Biermann (2014) used life satisfaction data to study European citizens' preferences for alternative structures of their national electricity supply system and found people's subjective well-being to be positively correlated with the share of solar and wind power in their national electricity mix. Using spatially disaggregated data from Australia, Ambrey and Fleming (2011) found scenic amenity to affect well-being, a result which may be relevant for the well-being assessment of RE facilities. Krekel and Zerrahn (2015) studied the relationship between German citizens' subjective well-being and the presence of wind turbines in their proximity and found well- 
being to be significantly lower in individuals who live within $4 \mathrm{~km}$ of distance from wind turbines.

\section{Method}

\subsection{Data}

Our data come from several sources. The data on life satisfaction along with information on the respondents' socio-economic situation is provided by the German Socio Economic Panel Study (SOEP) of the German Institute for Economic Research (DIW). The SOEP survey is conducted on a yearly basis since 1984 . Annual waves of the survey include more than 20,000 individuals in about 11,000 households. With respect to the spatial dimension, SOEP data are identified by respondents' postcode area from 1993 onwards (Wagner et al. 2007). ${ }^{2}$

An important attribute of the SOEP is its panel structure (i.e. that the same individuals are re-interviewed each year), which facilitates to analyze changes on the individual level and to control for unobserved time-invariant characteristics (Andreß et al. 2013). As respondents may join the panel at a later stage (late entry), drop-out in a single wave (temporary non unit response) or permanently (panel attrition) (e.g. due to refusal, death or relocation) the set of respondents is slightly changing over time, i.e. the data is unbalanced (Andreß et al. 2013).

The dependent variable in our life satisfaction regressions is the answer to the following question: "How satisfied are you at present with your life, all things considered? Please respond using the following scale, where ' 0 ' indicates not at all satisfied and ' 10 ' indicates completely satisfied."

The data set used in this paper refers to the waves 1994-2012 and includes 324,770 observations for 46,678 individuals. The variables of the SOEP used in this analysis are summarized in Table 1.

\footnotetext{
${ }^{2}$ Changing postcodes have not been re-coded in the SOEP which is why we used a manual search to - if possible - adjust postcodes in case more than five observations were affected. The same has been done with the energy dataset which partly included wrong or outdated postcodes.
} 
As to the energy data, the four German Transmission System Operators (TSO) Amprion, 50Hertz, Tennet and TransnetBW provide data on all RE plants that come under the Renewable Energy Act (EEG). ${ }^{3}$ Though the four sources are different with regard to their comprehensiveness, they all give information about the postcode area (5-digit hierarchical system) where the plant was installed, its type of technology (wind, solar, biomass, hydro, geothermal energy as well as landfill, mine and sewage gas), the date of construction and the installed capacity. Unfortunately, there is no information that would help us to distinguish between rooftop solar and free-standing installations. ${ }^{4}$ Nor can we obtain information about the sort of biomass plant, which may have implications for odor nuisance because of different material that is being combusted. For data on wind energy, a different source was used, that gives concise information on construction of wind turbines in Germany (BDB 2013). ${ }^{5}$ The energy variables used in this analysis are summarized in Table 2. From the summary statistics we can tell that wind energy has the greatest installed capacity of the three considered RE technologies and that most respondents have solar installations in their neighborhood. The standard deviations indicate that there is a considerable variance across observations.

We matched the data on RE plants and the socio-economic data of the SOEP on the basis of the respondents' postcode area. Moreover, as the exact dates of the interview and the plant constructions were available, we could identify for each respondent the number of plants and capacity installed per type of technology by the time of the interview. ${ }^{6}$ For each wave during 1994 to 2012 the final dataset gives information about the respondents' socioeconomic situation (see Table 1) as well as the presence of RE technologies in the

\footnotetext{
${ }^{3}$ Some RE plants exceeding a certain capacity are excluded from the EEG promotion. By the end of 2011 this concerned about $1 / 3$ of the hydroelectric installations while all of the other technologies were still eligible to achieve the EEG feed-in-tariff (BDEW 2013:19f).

${ }^{4}$ In the EEG a RE plant is defined very broadly as a facility to produce electricity from RE or mine gas. In the case of rooftop solar, all installations that are built on the same property within 12 months are subsumed as one plant. Free-standing solar installations are considered as one plant if they are built in the same community within a distance of $2 \mathrm{~km}$ and within a time-span of 24 months.

${ }^{5}$ This analysis is restricted to onshore wind energy.

${ }^{6}$ As for the wind data, we only know the month and year of construction, which is why we used the $15^{\text {th }}$ as the date of reference.
} 
respondents' postcode area (see Table 2). In Germany, there are about 8,200 postcode districts, on average comprising an area of $44 \mathrm{~km}^{2}$. In order to take account of possible spillover effects, we widened the spatial scale to include RE plants of neighboring postcode areas. Information from the open source platform OpenStreetMap was used to identify for each postcode area the adjacent postcode areas.

\subsection{General Methodological Issues}

Our approach to measuring externalities from RE involves approximating utility by data on subjective well-being, specifically, life satisfaction. Though this approach relies on subjective data, a major feature of this method is that it does not rely on people's stated attitude towards or stated evaluation of the issues under study. Instead, life satisfaction data are being elicited independently of those issues, and it is the purely statistical association between life satisfaction and the independently measured variables of interest that is taken as a measure of preference.

Assumptions necessary for using reported life satisfaction in longitudinal analysis are a positive monotonic relationship between life satisfaction and the underlying true utility, and ordinal intrapersonal comparability (see Ferrer-i-Carbonell and Frijters 2004, Faßhauer and Rehdanz 2015). This means that if the satisfaction score at time $t$ is greater than at time $t^{\prime}$, this reflects the same ranking of underlying utility. If, more restrictively, it is assumed that differences in satisfaction scores are proportional to differences in underlying utility, life satisfaction can be treated as a cardinal variable. Using SOEP data, Ferrer-i-Carbonell and Frijters (2004) found that assuming the data to be ordinal or cardinal and applying the corresponding estimation methods has little effect on qualitative results. In particular, the ratios of coefficients are similar, which is important for monetary valuation. Similar results were obtained by many others. In addition, Ferrer-i-Carbonell and Frijters (2004) stress the importance of including individual fixed-effects (thereby controlling for time-invariant 
characteristics such as personality traits), as their omission biases the results substantially. In contrast to estimators for cardinal data (least squares) there is no consensus as to appropriate methods for implementing individual fixed-effects in ordered regression models (Baetschmann et al. 2014).

\subsection{Econometric Approach}

We estimated micro-econometric life satisfaction functions in which the self-reported life satisfaction $(L S)$ of individual $i$ in postcode area $s$ and year $t$ depends on indicators of renewable energy $(R E)$ in her postcode area, income, and a standard set of time-variant sociodemographic controls (household size, age squared, health status, partner status, employment status, person in household needing care). Time-invariant factors are implicitly captured through person-specific fixed effects. The estimating equation can be stated as follows:

$$
L S_{i s t}=\alpha+\beta^{*} R E_{s t}+\gamma^{*} \ln \left(\text { income }_{i s t}\right)+\delta \text { controls }_{\text {ist }}+\text { person }_{i}+\text { year }_{t}+\varepsilon_{i s t}
$$

where person $_{i}$ and year $r_{t}$ denote person and year fixed effects, respectively, and $\varepsilon_{i s t}$ denotes the error term. Person fixed effects control for unobserved time-invariant characteristics of the individual (such as personality traits) whereas year fixed effects control for time-varying unobserved factors common to a particular year (such as the business cycle). The income variable is specified as the net monthly household income adjusted for inflation and equivalised according to the OECD-modified scale. As is common in the well-being literature, income is included in logarithmic form to account for decreasing marginal utility.

Equation (1) will be estimated for $R E$ referring to wind power, solar power and biomass, respectively. Several alternative indicators will be used for $R E$. One indicator is a dummy variable that takes the value 1 if at least one of the respective $R E$ plants exists in the respondent's postcode area and 0 otherwise. Alternative $R E$ indicators are the number of 
plants and the installed capacity. It should be noted that over time the $R E$ dummy variable changes its value only once (from 0 to 1 ), at the time of the first installation (unless the first installation took place before the period of observation or there is none). ${ }^{7}$ In contrast to the number of units and the installed capacity, the coefficient of the $R E$ dummy variable hence measures the effect of the first installation, not of subsequent expansions.

We will extend the basic specification, equation (1) by including, in addition to $R E$ in a respondent's own postcode area, the corresponding $R E$ indicator in the neighboring (adjacent) postcode areas. This specification serves to measure the existence and strength of spatial well-being spillovers.

In order to study the dynamics of RE externalities, we extended equation (1) to include dummy variables that represent leads and lags of the first installation of RE units. Specifically, letting $\mathrm{T}$ denote the year of the first installation, $\mathrm{D}(\mathrm{T}+\mathrm{i})$ is a dummy variable that takes the value one in $\mathrm{T}+\mathrm{i}$ and zero otherwise, where $\mathrm{i}=\leq-3,-2,-1,0,1,2$ and $\mathrm{i} \geq 3$. The analysis is restricted to those individuals who actually experienced an RE installation in their postcode area. This reduces the number of observations to 94,497 for solar 29,851 for wind and 71,358 for biomass.

We minimize the risk of omitted variable bias by controlling for the observed timevarying life satisfaction factors known to be relevant (see Dolan et al. 2008 for a review) as well as for unobserved person-specific factors (through the FE modeling framework). Though life satisfaction is likely to be measured with error, there is no reason to expect that measurement error is correlated with our independent variables of interest. Finally, including person fixed effects is an effective way of dealing with reverse causation in life satisfaction regressions (Ferrer-i-Carbonnel and Frijters 2004).

\footnotetext{
${ }^{7}$ Unfortunately we do not have data on the decommissioning of $R E$ units, but this can be considered to be of minor importance in the time frame considered, given the typical lifetime of $R E$ installations.
} 
Following Ferrer-i-Carbonell and Frijters (2004), we treat the dependent variable, 11point life satisfaction, as a cardinal variable and estimate equation (1) and variants thereof using least squares. We report robust standard errors corrected for clustering at the individual level.

\section{Results and Discussion}

\subsection{Estimation Results}

Tables 3 - 5 present the estimation results for solar installations, wind turbines, and biomass plants, respectively. The presentation is restricted to the main variables of interest, whereas more detailed results, including those for the control variables, are reported in the Appendix. ${ }^{8}$

Table 3 reports the results for solar power for alternative specifications that differ according to two criteria: (i) solar power installations captured by a dummy variable, by their number, or by installed capacity, (ii) solar power installations in residents' own postcode area or in own area and adjacent areas. In the various specifications, not all coefficients of the RE variables are significant, but all significant coefficients are negative. When only the respondents' own postcode area is considered, the RE dummy variable is insignificant, suggesting that the first installation has no effect on well-being. By contrast, the number of units has a strongly significant coefficient and the capacity a weakly significant coefficient. When we add to those models the respective solar energy variables in adjacent areas, we find that all RE variables in the own area are insignificant, whereas the number and capacity in adjacent areas have negative effects on well-being.

We conclude that in the case of solar power no well-being externalities can be found from the first installation, neither in the individual's own area nor in adjacent areas. Instead,

\footnotetext{
${ }^{8}$ The results for the controls do not vary appreciably across the various specifications and are reported only for the main specifications. They correspond to those typically found in life satisfaction regressions for developed countries (Dolan et al. 2008): Life satisfaction is increasing in health and in income, greater if having a partner and smaller if unemployed than in any other employment status.
} 
well-being seems to be negatively affected by expansion in the number and capacity of installations, in particular in adjacent areas. When we control for installations in adjacent areas, no negative well-being effects from solar energy installations in one's own area can be found.

Table 4 reports the results for wind power; it is organized in the same way as Table 3. In contrast to solar power, the dummy variable is significantly negative. The number of plants has a weakly significantly negative coefficient, whereas capacity is insignificant. When we add to those models the respective wind energy variables in adjacent areas, we find the preceding results almost unaffected in terms of the sign, significance, and magnitude of the coefficients; only the capacity coefficient becomes weakly significant. The number and capacity in the adjacent areas are insignificant.

We conclude that in the case of wind power well-being externalities tend to arise from both the first installation and subsequent expansion in one's own area whereas there are no spillovers from adjacent areas.

Table 5 reports the results for power generation from biomass. All significant coefficients in the various specifications are negative. The coefficient of the dummy variable is strongly significant whereas the coefficients of the number and capacity are weakly significant. When we control for RE in adjacent areas, the number and capacity in the own area become insignificant, whereas all three RE variables in adjacent areas are significantly negative.

The results suggest that well-being effects of biomass plants exist with respect to both initial installations and further expansions. Moreover, initial installations and expansions in adjacent areas have significant negative well-being effects.

Table 6 reports the estimation results for the dynamics of RE externalities. The coefficients of the dummy variables $\mathrm{D}(\mathrm{T}+\mathrm{i})$ indicate whether and how life satisfaction in the respective year differs from life satisfaction before T-2. The lead coefficients indicate well- 
being effects from people's anticipation of the installation of RE facilities. Such effects may arise when the installation is publicly announced and debated in advance. The lag coefficients represent two effects. One is hedonic adaptation, which implies that coefficients become smaller in magnitude and less significant over time. The other arises from the fact that after the first installation there is usually an expansion in the number and capacity in a given postcode area. On average, the number and capacity of wind and biomass plants increased by a factor of 1.6 within the first three years. The number of solar installations increased by a factor of 4.6, while capacity increased by a factor of 6.6.

For solar power, the leads are insignificant whereas the coefficients for the year of the first installation and all subsequent years are significantly negative and increasing in magnitude. For wind power, $\mathrm{D}(\mathrm{T}-2)$ is insignificant, whereas $\mathrm{D}(\mathrm{T}-1)$ is weakly significantly negative. While the coefficient in the year of the first installation is negative but insignificant, the dummies for the following years are significantly negative, without an apparent trend. For biomass plants, all dummy variables are significantly negative. Their magnitude peaks in $\mathrm{T}+1$, after which time it tends to decline.

The result that leads are (weakly) significant for wind and biomass units but insignificant in the case of solar units is consistent with the observation that the first installation of wind and biomass plants is often preceded by public announcement and debate. This does not apply to solar units, at least those of the rooftop variety. After the first installation, however, there is typically a drastic expansion of solar power (by a factor of 4.6 within three years), which may dominate the effect of adaptation. In the case of wind power, expansion after the first installation is less drastic. This may imply that though there has been some concern before the first installation, this concern is attenuated when the event actually happens and rises again only when numbers or capacities are further increased. ${ }^{9}$ Regarding

\footnotetext{
${ }^{9}$ Concern about the installation of wind power plants at the time of public debate which fades away when the turbines are installed is a case of so-called focusing illusion.
} 
biomass plants, the attenuation of concern seems to be absent. One possible explanation could be that the nuisance from biomass plants (odor) is more difficult to avoid by averting behavior than is the nuisance from wind turbines (mainly visual impairment).

\subsection{Discussion}

We found that renewable power plants generate statistically and substantively significant negative local externalities, but the effects of the technologies considered - solar, wind, and biomass - differ qualitatively and quantitatively.

For solar power we found no well-being effects of initial installations, but effects from subsequent expansion. From a spatial point of view, mainly solar installations in neighboring postcode areas seem to affect people's well-being, not those in their own postcode area.

An important factor that may explain those findings is that solar installations - at least the rooftop variety - are typically owned by local residents, who benefit from reduced electricity expenditures and/or feed-in revenues. In addition, there might be status effects associated with the presence of solar panels on ones' rooftop (Sonnberger 2015). First installations of solar units are of small size and capacities grow gradually, such that impairments - which are mainly visual - are likely to arise from the accumulation of capacity, not from first installations. Moreover, according to our results those impairments largely originate not from installations in people's own area but from those in neighboring areas for which the monetary and status benefits are more likely to accrue to others, not to oneself. ${ }^{10}$

For wind power, the results suggest that well-being effects arise both from initial installations and subsequent expansions. There do not seem to be spatial externalities from neighboring postcode areas.

\footnotetext{
${ }^{10}$ Insignificance of solar installations in one's own area when installations in adjacent areas are controlled for suggests the presence of omitted variable bias in the specifications that lack those controls.
} 
These findings are explicable because wind power installations differ in important ways from solar installations: They are typically owned by external investors, such that there are less local benefits than in the case of solar power. In addition, citizens' participation in the decision process is often limited. Moreover, visual impairments can be avoided by averting behavior, in particular when installations are not in close proximity. This may explain the absence of spatial spillovers. Acoustic impairments depend on proximity and are thus also less liable to spatial spillovers.

For biomass plants, the estimates suggest a difference between the own area and adjacent areas. While first installations in both the own and adjacent areas affect well-being, expansions have effects only if they take place in adjacent, not own areas.

The difference between own and adjacent areas is consistent with the circumstance that biomass plants are often locally owned, hence local impairments tend to be offset by local benefits while impairments from neighboring areas are not. In addition, odor nuisance from biomass plants is difficult to avoid by averting behavior. Moreover, odor nuisance may be less related to proximity than are the visual and acoustic impairments from wind turbines.

\subsection{Quantifying Renewable Energy Externalities}

Tables 7 and 8 present overviews of the estimated well-being effects of RE both in units of life satisfaction and in monetary terms. The monetary values are obtained by dividing the coefficients on the respective RE variables by the coefficient on log income, which yields the marginal rate of substitution between RE and log income or the percentage change of income required to compensate for a 1-unit increase in the RE variable.

As reported in Table 7, the presence of wind energy plants in one's own postcode area is associated with a reduction in 11-point life satisfaction by 0.033 to 0.036 (depending on whether wind energy plants in adjacent areas are controlled for or not). This corresponds to about 6 to 7 percent of the effect of being unemployed, which is one of the most important 
adverse factors for LS (the coefficient being -0.52 to -0.55 , see Appendix). In monetary terms it corresponds to 10.4 to 11.3 percent of equivalized income. Evaluated at the mean of equivalized monthly income $(1,642.252$ Euro, see Table 1$)$, the presence of at least one wind turbine in one's postcode area is equivalent to a decrease in equivalized monthly income by 168 to 183 Euros. $^{11}$

The presence of biomass plants in one's own postcode area is associated with a reduction in 11-point life satisfaction by 0.036 to 0.039 (depending on whether biomass plants in adjacent areas are controlled for or not), corresponding to 183 to 198 Euros of equivalized monthly income.

Turning to RE capacities (Table 8), an increase of wind power capacity by $1 \mathrm{MW}$ in one's own postcode area is associated with a decrease in 11-point life satisfaction by 0.0010 , corresponding to 0.31 percent of equivalized monthly income or 5.2 Euros. An increase in solar capacity by $1 \mathrm{MW}$ in adjacent areas is associated with a decrease in satisfaction by 0.0023 points, which corresponds to 0.72 percent of equivalized monthly income or 11.9 Euros. For biomass plants, an increase by $1 \mathrm{MW}$ in adjacent areas is associated with a decrease in life satisfaction by 0.0014 points, corresponding to 0.44 percent or 7.2 Euros of equivalized monthly income.

\section{Conclusion}

This paper has used representative nationwide panel data on the life satisfaction of German citizens for identifying and valuing the local externalities from wind, solar and biomass plants. We found that renewable power plants generate statistically and economically significant local externalities whose effects differ across the technologies considered, both qualitatively and quantitatively. Our qualitative findings on the well-being externalities of the

${ }^{11}$ Multiplying our estimates by 12 yields 2,045 to 2,231 Euros of annual income. In their study of the relationship between wind turbines and residential well-being, Krekel and Zerrahn (2015) assume a lifetime of 20 years and find the monetary equivalent of one wind turbine within a distance of 4000 meters to be 59 Euros per year, which under the assumed lifetime implies a total value of 1180 Euros (20x59). 
different RE technologies are in line with those technologies' characteristics and the channels of influence through which they affect well-being.

In relation to previous literature, a major advantage of the present study is the use of a rich set of nationwide representative panel data merged with spatially disaggregated data on the location and expansion of several types of RE technologies. This has allowed us to conduct a longitudinal analysis of externalities associated with RE.

A limitation of our study relates to our inability to differentiate solar plants into rooftop installations and free-standing installations. Such a differentiation would be important because the latter are less likely to be locally owned than the former. In addition, the visual impairments from free-standing installations may differ from those from rooftop installations. Similar considerations apply to different varieties of biomass plants that we are unable to differentiate. Another issue to be noted is the fact that the spatial units we use (postcode areas) differ with regard to their size. Since wind turbines and biomass plants are usually constructed in less densely populated areas (where one postcode may well comprise several villages), it is noteworthy that we still find significant well-being effects from these types of plants.

We translated the estimated well-being effects into monetary equivalents but acknowledge that the results may be biased due to endogeneity of income. By instrumenting income, previous studies have shown that the income coefficients may increase by factors of 2 to 3 , resulting in correspondingly lower monetary values of the non-market goods under study. However, there is no consensus on appropriate instruments (see e.g. Faßhauer and Rehdanz 2015).

As to policy conclusions, our findings do not imply a dismissal of RE in general since conventional (fossil and nuclear) power generation technologies have externalities of their own (air pollution, greenhouse gases, nuclear risk). Rather, to further increase local acceptance, in particular of wind parks, monetary compensation of externalities might be contemplated. 
Besides considering more differentiated RE technologies, future research may investigate local RE externalities in comparison with externalities from fossil and nuclear power plants and extend those analyses to countries other than Germany. Moreover, by using geocodes and an energy dataset that distinguishes between different types and sizes of solar and biomass plants one could further refine the analysis. 


\section{References}

Ambrey, C. L., Fleming, C. M. (2011), Valuing scenic amenity using life satisfaction data, Ecological Economics 72, 106-115.

Andreß, H.-J., Golsch, K., Schmidt, A. W. (2013), Applied Panel Data Analysis for Economic and Social Surveys, Berlin; Heidelberg: Springer.

Baetschmann, G., Staub, K. E., Winkelmann, R. (2014), Consistent Estimation of the Fixed Effects Ordered Logit Model, Journal of the Royal Statistical Society: Series A (Statistics in Society) 178, Nr. 3 (2015): 685-703.

Batel, S., Devine-Wright, P., Tangeland, T. (2013), Social acceptance of low carbon energy and associated infrastructures: A critical discussion, Energy Policy 58, 1-5.

BDB (2013), Betreiberdatenbank für Windenergieanlagen, http://www.btrdb.de/sto.html, Jochen Keiler.

BDEW (2013), Erneuerbare Energien und das EEG: Zahlen, Fakten, Graphiken (2013), Bundesverband der Energie- und Wasserwirtschaft e.V., Berlin.

Chiabrando, R., Fabrizio, E., Garnero, G. (2009), The territorial and landscape impacts of photovoltaic systems: Definition of impacts and assessment of the glare risk, Renewable and Sustainable Energy Reviews 13, 2441-51.

Devine-Wright, P. (2007), Reconsidering public attitudes and public acceptance of RE technologies: a critical review, Working Paper 1.4, School of Environment and Development, University of Manchester, Manchester, UK.

Diener, E., Suh, E.M., Lucas, R.E., Smith, H.L. (1999), Subjective Well-Being: Three Decades of Progress, Psychological Bulletin 125, 276-302.

Dolan, P., Peasgood, T., White, M., (2008), Do we really know what makes us happy? A review of the economic literature on the factors associated with subjective well-being, Journal of Economic Psychology 29, 94-122. 
Drechsler, M., Ohl, C., Meyerhoff, J., Eichhorn, M., Monsees, J. (2011), Combining spatial modeling and choice experiments for the optimal spatial allocation of wind turbines, Energy Policy 39, 3845-3854.

Faßhauer, A., Rehdanz, K. (2015), Estimating Benefits from Regional Amenities: Internal Migration and Life Satisfaction, SOEP Paper on Multidisciplinary Panel Data Research No. 748.

Ferrer-i-Carbonell A., Frijters, P. (2004), How Important is Methodology for the Estimates of the Determinants of Happiness?, Economic Journal 114, 641-659.

Frey, B.S., Stutzer, A. (2002), What Can Economists Learn from Happiness Research?, Journal of Economic Literature 40(2), 402-435.

Frey, B.S., Luechinger, S., Stutzer, A. (2010), The Life Satisfaction Approach to Environmental Valuation. Annual Review of Resource Economics 2, 139-160.

Fujiwara, D., Campbell, R. (2011), Valuation techniques for social cost-benefit analysis, HM Treasury.

Hoen, B., Brown, J. P., Jackson, T., Wiser, R., Thayer, M., Cappers, P. (2013), A Spatial Hedonic Analysis of the Effects of Wind Energy Facilities on Surrounding Property Values in the United States, LBNL paper LBNL-6362e, Lawrence Berkeley National Laboratory.

Jensen, C. U., Panduro, T. E., Lundhede, T. H. (2013), The Vindication of Don Quijote: The impact of noise and visual pollution from wind turbines on local residents in Denmark, IFRO Working Paper 2013/13, University of Copenhagen, Department of Food and Resource Economics.

Kahneman, D. Thaler, R. H. (2006), Anomalies: Utility Maximization and Experienced Utility, Journal of Economic Perspectives 20, 221-234.

Krekel, C., Zerrahn, A. (2015), Sowing the Wind and Reaping the Whirlwind? The Effect of Wind Turbines on Residential Well-Being, SOEP Paper on Multidisciplinary Panel Data Research No. 760. 
Levinson, A. (2012), Valuing Public Goods Using Happiness Data: The Case of Air Quality, Journal of Public Economics 96: 869-880.

MacKerron, G. (2012), Happiness Economics from 35000 Feet, Journal of Economic Surveys $26,705-735$.

MacKerron, G., Mourato, S. (2013), Happiness is Greater in Natural Environments, Global Environmental Change 23, 992-1000.

Meyerhoff, J. (2013), Do turbines in the vicinity of respondents' residences influence choices among programmes for future wind power generation?, Journal of Choice Modelling 7, $58-71$.

Meyerhoff, J., Ohl, C., Hartje, V. (2010), Landscape externalities from onshore wind power, Energy Policy 38, 82-92.

Rehdanz, K., Maddison, D. (2005), Climate and Happiness, Ecological Economics 52, 111125.

Socio-Economic Panel (SOEP), data for years 1994-2012, version 29, SOEP, 2013, doi:10.5684/soep.v29.

Soland, Steimer, M., N., Walter, G. (2013), Local acceptance of existing biogas plants in Switzerland, Energy Policy 61, 802-810.

Sonnberger, M. (2015), Der Erwerb von Photovoltaikanlagen in Privathaushalten - Eine empirische Untersuchung der Handlungsmotive, Treiber und Hemmnisse, Springer Fachmedien Wiesbaden.

Sunak, Y., Madlener, R. (2012), The Impact of Wind Farms on Property Values: A Geographically Weighted Hedonic Pricing Model, FCN working paper no. 3/2012, Institute for Future Energy Consumer Needs and Behavior, RWTH Aachen University.

Van der Horst, D. (2007), NIMBY or not? Exploring the relevance of location and the politics of voiced opinions in renewable energy siting controversies, Energy Policy 35, 2705-2714. 
VZBV (2013), Verbraucherinteressen in der Energiewende - Ergebnisse einer repräsentativen Befragung, Verbraucherzentrale Bundesverband, Berlin.

Wagner, G.G. Frick, J.R., Schupp, J. (2007), The German Socio-Economic Panel Study (SOEP): Scope, Evolution and Enhancement, Schmollers Jahrbuch / Journal of Applied Social Sciences Studies 127, 139-169.

Welsch, H. (2002), Preferences over Prosperity and Pollution: Environmental Valuation Based on Happiness Surveys, Kyklos 55, 473-494.

Welsch, H., Biermann, P. (2014), Electricity Supply Preferences in Europe: Evidence from Subjective Well-Being Data, Resource and Energy Economics 38, 38-60.

Welsch, H. Ferreira, S. (2014), Environment, Well-Being, and Experienced Preference, International Review of Environmental and Resource Economics 7, 205-239.

Welsch, H., Kühling, J. (2009), Using Happiness Data for Environmental Valuation: Issues and Applications, Journal of Economic Surveys 23, 473-494.

Wüstenhagen, R., M. Wolsink, and M. J. Bürer (2007), Social acceptance of renewable energy innovation: An introduction to the concept, Energy Policy 35, 2683-2691. 
Table 1: Summary Statistics of Socio-Economic Data

\begin{tabular}{|c|c|c|c|c|c|}
\hline Variable & Description & Mean & Std. Dev. & Min & Max \\
\hline $\begin{array}{c}\text { Life } \\
\text { Satisfaction }\end{array}$ & $\begin{array}{l}11 \text {-point scale. } 0 \text { corresponds } \\
\text { to completely dissatisfied and } 10 \text { to } \\
\text { completely satisfied. }\end{array}$ & 6.962 & 1.781 & 0 & 10 \\
\hline $\begin{array}{l}\text { Real Equivalent } \\
\text { Household } \\
\text { Income } \\
\end{array}$ & $\begin{array}{l}\text { Monthly net household income is deflated } \\
\text { by means of CPI data and equivalized } \\
\text { according to the OECD-modified scale. }\end{array}$ & $1,642.252$ & $1,075.117$ & 0 & $133,333.3$ \\
\hline Household Size & $\begin{array}{l}\text { This variable describes the number of } \\
\text { persons living in the respondent's } \\
\text { household. }\end{array}$ & 2.761 & 1.298 & 1 & 14 \\
\hline Age & $\begin{array}{l}\text { This variable gives information about the } \\
\text { respondent's age. }\end{array}$ & 47.175 & 17.671 & 15 & 102 \\
\hline $\begin{array}{l}\text { Person Needing } \\
\text { Care in } \mathrm{HH}\end{array}$ & $\begin{array}{l}\text { The dummy specifies whether there is a } \\
\text { person in the household in need of care } \\
(1) \text {, or not }(0) \text {. }\end{array}$ & 0.0420 & 0.201 & 0 & 1 \\
\hline $\begin{array}{l}\text { Health Status: } \\
\text { Very Good }\end{array}$ & $\begin{array}{l}\text { The dummy variable takes the value } 1 \text { if } \\
\text { health status is perceived as very good, and } \\
0 \text { otherwise. }\end{array}$ & 0.095 & 0.294 & 0 & 1 \\
\hline $\begin{array}{l}\text { Health Status: } \\
\text { Good }\end{array}$ & $\begin{array}{l}\text { The dummy variable takes the value } 1 \text { if } \\
\text { health status is perceived as good, and } 0 \\
\text { otherwise. }\end{array}$ & 0.404 & 0.491 & 0 & 1 \\
\hline $\begin{array}{l}\text { Health Status: } \\
\text { Satisfactory }\end{array}$ & $\begin{array}{l}\text { The dummy variable takes the value } 1 \text { if } \\
\text { health status is perceived as satisfactory, } \\
\text { and } 0 \text { otherwise. }\end{array}$ & 0.328 & 0.469 & 0 & 1 \\
\hline $\begin{array}{l}\text { Health Status: } \\
\text { Poor }\end{array}$ & $\begin{array}{l}\text { The dummy variable takes the value } 1 \text { if } \\
\text { health status is perceived as poor, and } 0 \\
\text { otherwise. }\end{array}$ & 0.134 & 0.341 & 0 & 1 \\
\hline $\begin{array}{l}\text { Health Status: } \\
\text { Bad }\end{array}$ & $\begin{array}{l}\text { The dummy variable takes the value } 1 \text { if } \\
\text { health status is perceived as bad, and } 0 \\
\text { otherwise. }\end{array}$ & 0.038 & 0.190 & 0 & 1 \\
\hline Employed & $\begin{array}{l}\text { This dummy variable specifies whether the } \\
\text { respondent is employed (1), or not }(0) \text {. }\end{array}$ & 0.483 & 0.499 & 0 & 1 \\
\hline Not Employed & $\begin{array}{l}\text { This dummy variable specifies whether the } \\
\text { respondent is not employed }(1) \text {, or not }(0) \text {. }\end{array}$ & 0.080 & 0.271 & 0 & 1 \\
\hline Unemployed & $\begin{array}{l}\text { This dummy variable specifies whether the } \\
\text { respondent is unemployed (1), or not }(0) \text {. }\end{array}$ & 0.062 & 0.241 & 0 & 1 \\
\hline Pensioner & $\begin{array}{l}\text { This dummy variable specifies whether the } \\
\text { respondent is pensioner }(1) \text {, or not }(0) \text {. }\end{array}$ & 0.236 & 0.424 & 0 & 1 \\
\hline $\begin{array}{l}\text { Military, } \\
\text { Community } \\
\text { Service } \\
\end{array}$ & $\begin{array}{l}\text { This dummy variable specifies whether the } \\
\text { respondent is in Military or Community } \\
\text { Service (1), or not }(0) \text {. }\end{array}$ & 0.003 & 0.057 & 0 & 1 \\
\hline In Education & $\begin{array}{l}\text { This dummy variable specifies whether the } \\
\text { respondent is in education }(1) \text {, or not }(0) \text {. }\end{array}$ & 0.079 & 0.270 & 0 & 1 \\
\hline Self-Employed & $\begin{array}{l}\text { This dummy variable specifies whether the } \\
\text { respondent is self-employed (1), or not }(0) \text {. }\end{array}$ & 0.057 & 0.232 & 0 & 1 \\
\hline No Partner & $\begin{array}{l}\text { This dummy variable takes the value } 1 \text { in } \\
\text { case the respondent has no partner, and } 0 \\
\text { otherwise. }\end{array}$ & 0.216 & 0.412 & 0 & 1 \\
\hline $\begin{array}{l}\text { Partner Outside } \\
\text { Household }\end{array}$ & $\begin{array}{l}\text { This dummy variable takes the value } 1 \text { in } \\
\text { case the respondent has a partner outside } \\
\text { the household, and } 0 \text { otherwise. }\end{array}$ & 0.082 & 0.274 & 0 & 1 \\
\hline $\begin{array}{l}\text { Partner Inside } \\
\text { Household }\end{array}$ & $\begin{array}{l}\text { This dummy variable takes the value } 1 \text { in } \\
\text { case the respondent has a partner inside the } \\
\text { household, and } 0 \text { otherwise. }\end{array}$ & 0.702 & 0.457 & 0 & 1 \\
\hline
\end{tabular}


Table 2: Summary Statistics of Energy Data

\begin{tabular}{|c|c|c|c|c|c|c|c|}
\hline & Variable & Description & Reg. Scale & Mean & Std.Dev. & Min & Max \\
\hline \multirow{6}{*}{ 章 } & \multirow{2}{*}{ Dummy } & \multirow{2}{*}{$\begin{array}{l}\text { This dummy takes the value } 1 \text { in case } \\
\text { there is a solar installation in the } \\
\text { respective area, and } 0 \text { if not. }\end{array}$} & Own postcode & 0.816 & 0.387 & 0 & 1 \\
\hline & & & Adj. postcodes & 0.942 & 0.234 & 0 & 1 \\
\hline & \multirow{2}{*}{$\begin{array}{l}\text { Number } \\
\text { of Plants }\end{array}$} & \multirow{2}{*}{$\begin{array}{l}\text { This variable describes the total } \\
\text { number of solar installations in the } \\
\text { respective area. }\end{array}$} & Own postcode & 38.692 & 83.845 & 0 & 1,424 \\
\hline & & & Adj. postcodes & 199.872 & 380.875 & 0 & 6,233 \\
\hline & \multirow{2}{*}{$\begin{array}{l}\text { Capacity } \\
\text { Installed } \\
{[\mathrm{MW}]}\end{array}$} & \multirow{2}{*}{$\begin{array}{l}\text { This variable specifies the total } \\
\text { capacity installed (in MW) of solar } \\
\text { installations in the respective area. }\end{array}$} & Own postcode & 0.612 & 2.499 & 0 & 152.538 \\
\hline & & & Adj. postcodes & 3.173 & 8.672 & 0 & 321.750 \\
\hline \multirow{6}{*}{${ }_{3}^{3}$} & \multirow{2}{*}{ Dummy } & \multirow{2}{*}{$\begin{array}{l}\text { This dummy takes the value } 1 \text { in case } \\
\text { there is a wind turbine in the } \\
\text { respective area, and } 0 \text { if not. }\end{array}$} & Own postcode & 0.238 & 0.426 & 0 & 1 \\
\hline & & & Adj. postcodes & 0.536 & 0.499 & 0 & 1 \\
\hline & \multirow{2}{*}{$\begin{array}{l}\text { Number } \\
\text { of Plants }\end{array}$} & \multirow{2}{*}{$\begin{array}{l}\text { This variable describes the total } \\
\text { number of wind turbines in the } \\
\text { respective area. }\end{array}$} & Own postcode & 2.457 & 11.566 & 0 & 277 \\
\hline & & & Adj. postcodes & 13.279 & 34.030 & 0 & 498 \\
\hline & \multirow{2}{*}{$\begin{array}{l}\text { Capacity } \\
\text { Installed } \\
{[\mathrm{MW}]}\end{array}$} & \multirow{2}{*}{$\begin{array}{l}\text { This variable specifies the total } \\
\text { capacity installed (in MW) of wind } \\
\text { turbines in the respective area. }\end{array}$} & Own postcode & 2.609 & 13.492 & 0 & 378.671 \\
\hline & & & Adj. postcodes & 14.409 & 41.531 & 0 & 627.294 \\
\hline \multirow{6}{*}{ 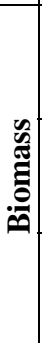 } & \multirow{2}{*}{ Dummy } & \multirow{2}{*}{$\begin{array}{l}\text { This dummy takes the value } 1 \text { in case } \\
\text { there is a biomass plant in the } \\
\text { respective area, and } 0 \text { if not. }\end{array}$} & Own postcode & 0.202 & 0.401 & 0 & 1 \\
\hline & & & Adj. postcodes & 0.484 & 0.499 & 0 & 1 \\
\hline & \multirow{2}{*}{$\begin{array}{l}\text { Number } \\
\text { of Plants }\end{array}$} & \multirow{2}{*}{$\begin{array}{l}\text { This variable describes the total } \\
\text { number of biomass plants in the } \\
\text { respective area. }\end{array}$} & Own postcode & 0.486 & 1.505 & 0 & 52 \\
\hline & & & Adj. postcodes & 2.663 & 5.876 & 0 & 149 \\
\hline & \multirow{2}{*}{$\begin{array}{l}\text { Capacity } \\
\text { Installed } \\
{[\mathrm{MW}]}\end{array}$} & \multirow{2}{*}{$\begin{array}{l}\text { This variable specifies the total } \\
\text { capacity installed (in MW) of } \\
\text { biomass plants in the respective area. }\end{array}$} & Own postcode & 0.334 & 2.014 & 0 & 141.863 \\
\hline & & & Adj. postcodes & 1.806 & 6.493 & 0 & 161.574 \\
\hline
\end{tabular}


Table 3: Estimation Results for Solar Energy

\begin{tabular}{|c|c|c|c|c|c|c|}
\hline & Dummy & Number & Capacity & Dummy & Number & Capacity \\
\hline RE own postcode & $\begin{array}{l}0.0059 \\
(0.0117)\end{array}$ & $\begin{array}{l}-0.0432 * * * \\
(0.0065)\end{array}$ & $\begin{array}{l}-0.0025^{*} \\
(0.0015)\end{array}$ & $\begin{array}{l}0.0038 \\
(0.0118)\end{array}$ & $\begin{array}{l}-0.0068 \\
(0.0101)\end{array}$ & $\begin{array}{l}0.0006 \\
(0.0016)\end{array}$ \\
\hline RE adjacent postcodes & & & & $\begin{array}{l}0.0156 \\
(0.0163)\end{array}$ & $\begin{array}{l}-0.0109 * * * \\
(0.0025)\end{array}$ & $\begin{array}{l}-0.0023 * * * \\
(0.0006)\end{array}$ \\
\hline $\begin{array}{l}\text { Log. Real Equivalent } \\
\text { HH-Income }\end{array}$ & $\begin{array}{l}0.3182 * * * \\
(0.0119)\end{array}$ & $\begin{array}{l}0.3181 * * * \\
(0.0119)\end{array}$ & $\begin{array}{l}0.3182 * * * \\
(0.0119)\end{array}$ & $\begin{array}{l}0.3182 * * * \\
(0.0119)\end{array}$ & $\begin{array}{l}0.3183 * * * \\
(0.0119)\end{array}$ & $\begin{array}{l}0.3181 * * * \\
(0.0119)\end{array}$ \\
\hline Other controls & yes & Yes & yes & yes & yes & yes \\
\hline Observations & 324,770 & 324,770 & 324,770 & 324,770 & 324,770 & 324,770 \\
\hline R-squared (within) & 0.1062 & 0.1064 & 0.1062 & 0.1062 & 0.1065 & 0.1063 \\
\hline
\end{tabular}

Note: Standard Errors in parenthesis are adjusted for clustering at the individual level. Installed capacity in MW, Number of Plants in 100. 
Table 4: Estimation Results for Wind Energy

\begin{tabular}{|l|l|l|l|l|l|l|}
\hline & Dummy & Number & Capacity & Dummy & Number & Capacity \\
\hline RE own postcode & $-0.0326^{* *}$ & $-0.1376^{*}$ & -0.0009 & $-0.0355^{* *}$ & $-0.1382^{*}$ & $-0.0010^{*}$ \\
& $(0.0154)$ & $(0.0765)$ & $(0.0005)$ & $(0.0155)$ & $(0.0826)$ & $(0.0006)$ \\
\hline RE adjacent postcodes & & & & $0.0224 *$ & 0.0004 & 0.0001 \\
& & & & $(0.0135)$ & $(0.0240)$ & $(0.0002)$ \\
\hline Log. Real Equivalent & $0.3184^{* * *}$ & $0.3182^{* * *}$ & $0.3182^{* * *}$ & $0.3181^{* * *}$ & $0.3182^{* * *}$ & $0.3181^{* * *}$ \\
HH-Income & $(0.0119)$ & $(0.0119)$ & $(0.0119)$ & $(0.0119)$ & $(0.0119)$ & $(0.0119)$ \\
\hline Other controls & Yes & yes & yes & yes & yes & yes \\
\hline Observations & 324,770 & 324,770 & 324,770 & 324,770 & 324,770 & 324,770 \\
\hline R-squared (within) & 0.1062 & 0.1062 & 0.1062 & 0.1062 & 0.1062 & 0.1062 \\
\hline
\end{tabular}

Note: Standard Errors in parenthesis are adjusted for clustering at the individual level. Installed capacity in MW, number of plants in 100 . 
Table 5: Estimation Results for Biomass

\begin{tabular}{|l|l|l|l|l|l|l|}
\hline & Dummy & Number & Capacity & Dummy & Number & Capacity \\
\hline RE own postcode & $-0.0385^{* * *}$ & $-0.6093^{*}$ & $-0.0038^{*}$ & $-0.0355^{* * *}$ & -0.2221 & -0.0036 \\
& $(0.0116)$ & $(0.3149)$ & $(0.0023)$ & $(0.0117)$ & $(0.3564)$ & $(0.0022)$ \\
\hline RE adjacent postcodes & & & & $-0.0283^{* * *}$ & $-0.2055^{* *}$ & $\begin{array}{l}-0.0014 * \\
(0.0007)\end{array}$ \\
& & & & $(0.0098)$ & $(0.0974)$ & $(0.007)$ \\
\hline Log. Real Equivalent & $0.3184^{* * *}$ & $0.3181^{* * *}$ & $0.3182^{* * *}$ & $0.3186^{* * *}$ & $0.3182^{* * *}$ & $0.3182^{* * *}$ \\
HH-Income & $(0.0119)$ & $(0.0119)$ & $(0.0119)$ & $(0.0119)$ & $(0.0119)$ & $(0.0119)$ \\
\hline Other controls & yes & yes & yes & yes & yes & yes \\
\hline Observations & 324,770 & 324,770 & 324,770 & 324,770 & 324,770 & 324,770 \\
\hline R-squared (within) & 0.1063 & 0.1062 & 0.1062 & 0.1063 & 0.1062 & 0.1062 \\
\hline
\end{tabular}

Note: Standard Errors in parenthesis are adjusted for clustering at the individual level. Installed capacity in MW, number of plants in 100 . 
Table 6: Dynamics of RE externalities

\begin{tabular}{|l|l|l|l|}
\hline & Solar & Wind & Biomass \\
\hline $\mathrm{D}(\mathrm{T}-2)$ & -0.0200 & -0.0148 & $-0.0687 * * *$ \\
& $(0.0238)$ & $(0.0391)$ & $(0.0234)$ \\
\hline $\mathrm{D}(\mathrm{T}-1)$ & -0.0208 & $-0.0796^{*}$ & $-0.0847 * * *$ \\
& $(0.0232)$ & $(0.0407)$ & $(0.0268)$ \\
\hline $\mathrm{D}(\mathrm{T})$ & $-0.0728^{* * *}$ & -0.0568 & $-0.0997 * * *$ \\
& $(0.0263)$ & $(0.0443)$ & $(0.0293)$ \\
\hline $\mathrm{D}(\mathrm{T}+1)$ & $-0.1777^{* * *}$ & $-0.1766^{* * *}$ & $-0.1693 * * *$ \\
& $(0.0280)$ & $(0.0512)$ & $(0.0334)$ \\
\hline $\mathrm{D}(\mathrm{T}+2)$ & $-0.2257^{* * *}$ & $-0.1346^{* *}$ & $-0.1302^{* * *}$ \\
\hline \multirow{2}{*}{$\mathrm{D}(\mathrm{T}+\mathrm{i}), \mathrm{i} \geq 3$} & $(0.0312)$ & $(0.0524)$ & $(0.0384)$ \\
\hline Log. Real Equivalent HH- & $-0.2468^{* * *}$ & $-0.1604 * * *$ & $-0.1381^{* * *}$ \\
Income & $(0.0347)$ & $(0.0563)$ & $(0.0418)$ \\
\hline Other controls & $(0.0267)$ & $(0.0463)$ & $(0.0301)$ \\
\hline Observations & \multicolumn{1}{|c|}{ yes } & yes & yes \\
\hline R-squared & 94,497 & 29,851 & 71,358 \\
\hline Note: Standard Errors & 0.1155 & 0.1124 & 0.1040 \\
\hline
\end{tabular}

Note: Standard Errors in parenthesis are adjusted for clustering at the postcode level. Installed capacity measured in MW, number of plants measured in 100 . 
Table 7: Quantification of Renewable Energy Externalities: Presence of RE Plants in Own Postcode Area

\begin{tabular}{|l|l|l|l|l|l|l|}
\hline & \multicolumn{2}{|l|}{ Not Controlling for adjacent postcode areas } & \multicolumn{3}{l|}{ Controlling for adjacent postcode areas } \\
\hline & LS units & $\begin{array}{l}\text { Percent of } \\
\text { income }\end{array}$ & Euro & LS units & $\begin{array}{l}\text { Percent of } \\
\text { income }\end{array}$ & Euro \\
\hline Solar & n.s. & -- & -- & n.s. & -- & -- \\
\hline Wind & -0.033 & 10.2 & 168.1 & -0.036 & 11.2 & 183.0 \\
\hline Biomass & -0.039 & 12.1 & 198.6 & -0.036 & 11.1 & 183.0 \\
\hline
\end{tabular}

Note: Obtained from coefficients on RE dummy variables in Tables 3-5. n.s. = nonsignificant. 
Table 8: Quantification of Renewable Energy Externalities: Capacity (MW)

\begin{tabular}{|l|l|l|l|l|l|l|}
\hline & \multicolumn{4}{|l|}{ Own postcode area } & \multicolumn{3}{l|}{ Adjacent postcode areas } \\
\hline & LS units & $\begin{array}{l}\text { Percent of } \\
\text { income }\end{array}$ & Euro & LS units & $\begin{array}{l}\text { Percent of } \\
\text { income }\end{array}$ & Euro \\
\hline Solar & n.s. & -- & -- & -0.0023 & 0.72 & 11.9 \\
\hline Wind & -0.0010 & 0.31 & 5.2 & n.s. & -- & -- \\
\hline Biomass & n.s. & -- & -- & -0.0014 & 0.44 & 7.2 \\
\hline
\end{tabular}

Note: Obtained from coefficients in Tables 3-5 (regressions including own and adjacent postcode areas). n.s. = non-significant. 


\begin{tabular}{|c|c|c|c|c|c|c|c|c|c|}
\hline Appendix: Detailed Estimation Results & \multicolumn{3}{|c|}{ Solar Energy } & \multicolumn{3}{|c|}{ Wind Energy } & \multicolumn{3}{|c|}{ Biomass Energy } \\
\hline Dependent Variable: Life Satisfaction & (1a) & (1b) & (1c) & $(2 a)$ & (2b) & $(2 \mathrm{c})$ & (3a) & $(3 b)$ & $(3 \mathrm{c})$ \\
\hline Dummy & $\begin{array}{l}0.0059 \\
(0.0117)\end{array}$ & & & $\begin{array}{l}-0.0326^{* *} \\
(0.0154)\end{array}$ & & & $\begin{array}{l}-0.0385 * * * \\
(0.0116)\end{array}$ & & \\
\hline Number of Plants & & $\begin{array}{l}-0.0432 * * * \\
(0.0065) \\
\end{array}$ & & & $\begin{array}{l}-0.1376^{*} \\
(0.0765)\end{array}$ & & & $\begin{array}{l}-0.6093 * \\
(0.3149)\end{array}$ & \\
\hline Installed Capacity & & & $\begin{array}{l}-0.0025^{*} \\
(0.0015)\end{array}$ & & & $\begin{array}{l}-0.0009 \\
(0.0005)\end{array}$ & & & $\begin{array}{l}-0.0038^{*} \\
(0.0023)\end{array}$ \\
\hline Log. Real Equivalent HH-Income & $\begin{array}{l}0.3182^{* * *} \\
(0.0119) \\
\end{array}$ & $\begin{array}{l}0.3181 * * * \\
(0.0119) \\
\end{array}$ & $\begin{array}{l}0.3182^{* * *} \\
(0.0119) \\
\end{array}$ & $\begin{array}{l}0.3184^{* * *} \\
(0.0119)\end{array}$ & $\begin{array}{l}0.3182 * * * \\
(0.0119)\end{array}$ & $\begin{array}{l}0.3182^{* * *} \\
(0.0119)\end{array}$ & $\begin{array}{l}0.3184 * * * \\
(0.0119)\end{array}$ & $\begin{array}{l}0.3181^{* * *} \\
(0.0119)\end{array}$ & $\begin{array}{l}0.3182^{* * *} \\
(0.0119)\end{array}$ \\
\hline Age Squared & $\begin{array}{l}0.0000 \\
(0.0000)\end{array}$ & $\begin{array}{l}0.0000 \\
(0.0000)\end{array}$ & \begin{tabular}{|l|}
0.0000 \\
$(0.0000)$
\end{tabular} & $\begin{array}{l}0.0000 \\
(0.0000)\end{array}$ & $\begin{array}{l}0.0000 \\
(0.0000)\end{array}$ & $\begin{array}{l}0.0000 \\
(0.0000)\end{array}$ & $\begin{array}{l}0.0000 \\
(0.0000)\end{array}$ & $\begin{array}{l}0.0000 \\
(0.0000)\end{array}$ & $\begin{array}{l}0.0000 \\
(0.0000)\end{array}$ \\
\hline Household-Size & $\begin{array}{l}0.0109 * * \\
(0.0050)\end{array}$ & $\begin{array}{l}0.0117 * * \\
(0.0050)\end{array}$ & $\begin{array}{l}0.0110^{* *} \\
(0.0050)\end{array}$ & $\begin{array}{l}0.0113^{* *} \\
(0.0050)\end{array}$ & $\begin{array}{l}0.0110^{* *} \\
(0.0050)\end{array}$ & $\begin{array}{l}0.0109^{* *} \\
(0.0050)\end{array}$ & $\begin{array}{l}0.0108^{* *} \\
(0.0050)\end{array}$ & $\begin{array}{l}0.0110^{* *} \\
(0.0050)\end{array}$ & $\begin{array}{l}0.0110^{* *} \\
(0.0050)\end{array}$ \\
\hline Person Needing Care in Household & $\begin{array}{l}-0.4368 * * * \\
(0.0257)\end{array}$ & $\begin{array}{l}-0.4363 * * * \\
(0.0257) \\
\end{array}$ & $\begin{array}{l}-0.4367 * * * * \\
(0.0257)\end{array}$ & $\begin{array}{l}-0.4369^{* * *} \\
(0.0257)\end{array}$ & $\begin{array}{l}-0.4359 * * * \\
(0.0257)\end{array}$ & $\begin{array}{l}-0.4361 * * * \\
(0.0257)\end{array}$ & $\begin{array}{l}-0.4368^{* * * *} \\
(0.0257) \\
\end{array}$ & $\begin{array}{l}-0.4367 * * * \\
(0.0257)\end{array}$ & $\begin{array}{l}-0.4368^{* * * *} \\
(0.0257)\end{array}$ \\
\hline \multicolumn{10}{|l|}{ Health Status: } \\
\hline - Good Health & $\begin{array}{l}-0.3418 * * * \\
(0.0104)\end{array}$ & \begin{tabular}{|l|}
$-0.3415 * * * *$ \\
$(0.0104)$
\end{tabular} & \begin{tabular}{|l|}
$-0.3417 * * * *$ \\
$(0.0104)$
\end{tabular} & $\begin{array}{l}-0.3417 * * * \\
(0.0104)\end{array}$ & $\begin{array}{l}-0.3418^{* * *} \\
(0.0104)\end{array}$ & $\begin{array}{l}-0.3418^{* * *} \\
(0.0104)\end{array}$ & $\begin{array}{l}-0.3419 * * * \\
(0.0104)\end{array}$ & $\begin{array}{l}-0.3417 * * * \\
(0.0104)\end{array}$ & $\begin{array}{l}-0.3417 * * * \\
(0.0104)\end{array}$ \\
\hline - Satisfactory Health & $\begin{array}{l}-0.7565 * * * \\
(0.0125)\end{array}$ & $\begin{array}{l}-0.7561 * * * \\
(0.0125)\end{array}$ & \begin{tabular}{|l|}
$-0.7564 * * * *$ \\
$(0.0125)$
\end{tabular} & $\begin{array}{l}-0.7565^{* * *} \\
(0.0125)\end{array}$ & $\begin{array}{l}-0.7565 * * * \\
(0.0125)\end{array}$ & $\begin{array}{l}-0.7565 * * * \\
(0.0125)\end{array}$ & $\begin{array}{l}-0.7565 * * * \\
(0.0125) \\
\end{array}$ & $\begin{array}{l}-0.7565 * * * \\
(0.0125)\end{array}$ & $\begin{array}{l}-0.7565 * * * \\
(0.0125)\end{array}$ \\
\hline - Poor Health & $\begin{array}{l}-1.3187 * * * \\
(0.0158)\end{array}$ & $\begin{array}{l}-1.3185 * * * \\
(0.0158)\end{array}$ & $\begin{array}{l}-1.3186^{* * * *} \\
(0.0158)\end{array}$ & $\begin{array}{l}-1.3187^{* * * *} \\
(0.0158)\end{array}$ & $\begin{array}{l}-1.3188 * * * \\
(0.0158)\end{array}$ & $\begin{array}{l}-1.3188 * * * \\
(0.0158)\end{array}$ & $\begin{array}{l}-1.3188^{* * * *} \\
(0.0158)\end{array}$ & $\begin{array}{l}-1.3187 * * * \\
(0.0158)\end{array}$ & $\begin{array}{l}-1.3187 * * * \\
(0.0158)\end{array}$ \\
\hline - Bad Health & $\begin{array}{l}-2.3719^{* * * *} \\
(0.0288)\end{array}$ & $\begin{array}{l}-2.3718 * * * \\
(0.0287)\end{array}$ & $\begin{array}{l}-2.3718^{* * * *} \\
(0.0288)\end{array}$ & $\begin{array}{l}-2.3720 * * * \\
(0.0288)\end{array}$ & $\begin{array}{l}-2.3718^{* * * *} \\
(0.0288)\end{array}$ & $\begin{array}{l}-2.3718 * * * \\
(0.0288)\end{array}$ & $\begin{array}{l}-2.3723 * * * \\
(0.0288)\end{array}$ & $\begin{array}{l}-2.3721 * * * \\
(0.0288)\end{array}$ & $\begin{array}{l}-2.3721 * * * \\
(0.0288)\end{array}$ \\
\hline \multicolumn{10}{|l|}{ Employment Status: } \\
\hline - Not Employed & $\begin{array}{l}-0.0581 * * * \\
(0.0165)\end{array}$ & \begin{tabular}{|l}
$-0.0600 * * *$ \\
$(0.0165)$
\end{tabular} & \begin{tabular}{|l}
$-0.0582 * * *$ \\
$(0.0165)$
\end{tabular} & $\begin{array}{l}-0.0581^{* * *} \\
(0.0165)\end{array}$ & $\begin{array}{l}-0.0579 * * * \\
(0.0165)\end{array}$ & $\begin{array}{l}-0.0579 * * * \\
(0.0165)\end{array}$ & $\begin{array}{l}-0.0579 * * * \\
(0.0165)\end{array}$ & $\begin{array}{l}-0.0583 * * * \\
(0.0165)\end{array}$ & $\begin{array}{l}-0.0581 * * * \\
(0.0165)\end{array}$ \\
\hline - Unemployed & $\begin{array}{l}-0.5260^{* * *} \\
(0.0170)\end{array}$ & $\begin{array}{l}-0.5258^{* * * *} \\
(0.0170)\end{array}$ & $\begin{array}{l}-0.5261 * * * \\
(0.0170)\end{array}$ & $\begin{array}{l}-0.5259 * * * \\
(0.0170)\end{array}$ & $\begin{array}{l}-0.5261 * * * \\
(0.0170)\end{array}$ & $\begin{array}{l}-0.5261^{* * *} \\
(0.0170)\end{array}$ & $\begin{array}{l}-0.5261 * * * \\
(0.0170)\end{array}$ & $\begin{array}{l}-0.5262 * * * \\
(0.0170)\end{array}$ & $\begin{array}{l}-0.5262 * * * \\
(0.0170)\end{array}$ \\
\hline - Retired & $\begin{array}{l}0.0579 * * * \\
(0.0180)\end{array}$ & $\begin{array}{l}0.0573 * * * \\
(0.0179)\end{array}$ & $\begin{array}{l}0.0578^{* * *} \\
(0.0179)\end{array}$ & $\begin{array}{l}0.0579 * * * \\
(0.0179)\end{array}$ & $\begin{array}{l}0.0579 * * * \\
(0.0180)\end{array}$ & $\begin{array}{l}0.0579 * * * \\
(0.0180)\end{array}$ & $\begin{array}{l}0.0577 * * * \\
(0.0179)\end{array}$ & $\begin{array}{l}0.0576^{* * *} \\
(0.0179)\end{array}$ & $\begin{array}{l}0.0579 * * * \\
(0.0180)\end{array}$ \\
\hline - Military, Community Service & $\begin{array}{l}0.0281 \\
(0.0446)\end{array}$ & $\begin{array}{l}0.0301 \\
(0.0447)\end{array}$ & $\begin{array}{l}0.0282 \\
(0.0447)\end{array}$ & $\begin{array}{l}0.0288 \\
(0.0446)\end{array}$ & $\begin{array}{l}0.0283 \\
(0.0447)\end{array}$ & $\begin{array}{l}0.0284 \\
(0.0447)\end{array}$ & $\begin{array}{l}0.0295 \\
(0.0447)\end{array}$ & $\begin{array}{l}0.0285 \\
(0.0447)\end{array}$ & $\begin{array}{l}0.0280 \\
(0.0447)\end{array}$ \\
\hline - In Education & $\begin{array}{l}0.1156^{* * *} \\
(0.0173)\end{array}$ & $\begin{array}{l}0.1168^{* * *} \\
(0.0173)\end{array}$ & $\begin{array}{l}0.1157 * * * \\
(0.0173)\end{array}$ & $\begin{array}{l}0.1162 * * * \\
(0.0173)\end{array}$ & $\begin{array}{l}0.1159^{* * *} \\
(0.0173)\end{array}$ & $\begin{array}{l}0.1158^{* * *} \\
(0.0173)\end{array}$ & $\begin{array}{l}0.1163^{* * *} \\
(0.0173)\end{array}$ & $\begin{array}{l}0.1158^{* * *} \\
(0.0173)\end{array}$ & $\begin{array}{l}0.1156^{* * *} \\
(0.0173)\end{array}$ \\
\hline - Self-Employed & $\begin{array}{l}0.0069 \\
(0.0241)\end{array}$ & $\begin{array}{l}0.0064 \\
(0.0241)\end{array}$ & $\begin{array}{l}0.0069 \\
(0.0241)\end{array}$ & $\begin{array}{l}0.0071 \\
(0.0241)\end{array}$ & $\begin{array}{l}0.0070 \\
(0.0241)\end{array}$ & $\begin{array}{l}0.0070 \\
(0.0241)\end{array}$ & $\begin{array}{l}0.0066 \\
(0.0241)\end{array}$ & $\begin{array}{l}0.0066 \\
(0.0241)\end{array}$ & $\begin{array}{l}0.0068 \\
(0.0241)\end{array}$ \\
\hline \multicolumn{10}{|l|}{ Partner Status: } \\
\hline - Partner Outside Household & $\begin{array}{l}0.2824 * * * \\
(0.0146)\end{array}$ & $\begin{array}{l}0.2823 * * * \\
(0.0146)\end{array}$ & $\begin{array}{l}0.2823 * * * \\
(0.0146)\end{array}$ & $\begin{array}{l}0.2825 * * * \\
(0.0146)\end{array}$ & $\begin{array}{l}0.2826 * * * \\
(0.0146)\end{array}$ & $\begin{array}{l}0.2826 * * * \\
(0.0146)\end{array}$ & $\begin{array}{l}0.2823 * * * \\
(0.0146)\end{array}$ & $\begin{array}{l}0.2825 * * * \\
(0.0146)\end{array}$ & $\begin{array}{l}0.2824 * * * \\
(0.0146)\end{array}$ \\
\hline - Partner Inside Household & $\begin{array}{l}0.4128 * * * \\
(0.0180)\end{array}$ & $\begin{array}{l}0.4117^{* * * *} \\
(0.0180)\end{array}$ & $\begin{array}{l}0.4126^{* * * *} \\
(0.0180)\end{array}$ & $\begin{array}{l}0.4122 * * * \\
(0.0180)\end{array}$ & $\begin{array}{l}0.4124 * * * \\
(0.0180)\end{array}$ & $\begin{array}{l}0.4124 * * * \\
(0.0180)\end{array}$ & $\begin{array}{l}0.4128^{* * * *} \\
(0.0180)\end{array}$ & $\begin{array}{l}0.4129^{* * *} \\
(0.0180)\end{array}$ & $\begin{array}{l}0.4127 * * * \\
(0.0180)\end{array}$ \\
\hline Year Dummies & yes & yes & yes & yes & yes & yes & yes & yes & yes \\
\hline Individual-specific Fixed Effects & yes & yes & yes & yes & yes & yes & yes & yes & yes \\
\hline R-squared (within) & 0.1062 & 0.1064 & 0.1062 & 0.1062 & 0.1062 & 0.1062 & 0.1063 & 0.1062 & 0.1062 \\
\hline Observations & 324,770 & 324,770 & 324,770 & 324,770 & 324,770 & 324,770 & 324,770 & 324,770 & 324,770 \\
\hline
\end{tabular}

Note: Standard Errors in parenthesis are adjusted for clustering at the individual level. Installed capacity in MW, number of plants in 100. 